\title{
IMPROVING THE CATALYTIC FEATURES OF THE LIPASE FROM Rhizomucor miehei IMMOBILIZED ON CHITOSAN-BASED HYBRID MATRICES BY ALTERING THE CHEMICAL ACTIVATION CONDITIONS
}

\author{
Elizabete Araújo Carneiro ${ }^{a}$, Ana Karine Pessoa Bastos ${ }^{\mathrm{b}}$, Ulisses Marcondes Freire de Oliveira ${ }^{\mathrm{c}}$, Leonardo José Brandão \\ Lima de Matos ${ }^{\mathrm{d}}$, Wellington Sabino Adriano ${ }^{\mathrm{e}}$, Rodolpho Ramilton de Castro Monteiro ${ }^{\mathrm{c}}$, José Cleiton Sousa dos Santos ${ }^{\mathrm{c}, \text {, } *, \text {,i] }}$ \\ and Luciana Rocha Barros Gonçalves ${ }^{c}$ \\ anstituto Federal do Ceará, Campus Quixadá, 63900-000 Quixadá - CE, Brasil \\ 'Eixo de Química e Meio Ambiente, Instituto Federal do Ceará, Campus Maracanaú, 61939-140 Maracanaú - CE, Brasil \\ 'Departamento de Engenharia Química, Universidade Federal do Ceará, Campus do Pici, 60455-760 Fortaleza - CE, Brasil \\ 'Instituto Federal do Maranhão, Campus Caxias, 65600-992 Caxias - MA, Brasil \\ eUniversidade Federal de Campina Grande, Centro de Educação e Saúde, Campus Cuité, 58175-000 Cuité - PB, Brasil \\ Instituto de Engenharias e Desenvolvimento Sustentável, Universidade da Integração Internacional da Lusofonia Afro-Brasileira, \\ Campus das Auroras, 62790-970 Redenção - CE, Brasil
}

Recebido em 24/04/2020; aceito em 30/06/2020; publicado em 21/08/2020

\begin{abstract}
The lipase from Rhizomисо miehei (RML) has been immobilized on chitosan-based hybrid (sodium alginate or carrageenan) matrices activated with glycidol (GLY), epichlorohydrin (EPI) or glutaraldehyde (GLU) groups. Then, the properties of the different biocatalysts have been evaluated and compared with the soluble RML. Thermal stability (at $\mathrm{pH} 7.0$ and $60{ }^{\circ} \mathrm{C}$ ) was significantly increased when compared to the soluble enzyme: 154-fold for chitosan 5.0\% - GLU, 80-fold for chitosan $2.5 \%$ - carrageenan $2.5 \%$ - GLY and 93 -fold for chitosan $2.5 \%$ - alginate $2.5 \%$ - EPI. The best biocatalyst preparation, which was 154-fold more stable than the soluble enzyme, was obtained when RML was immobilized on chitosan activated with glutaraldehyde 5.0\% v/v. According to the results, it was concluded that RML immobilization on chitosan-based hybrid matrices using different chemistries greatly produced biocatalysts with different properties.
\end{abstract}

Keywords: biocatalysts immobilization; lipase stabilization; modulation of lipase; glycidol; glutaraldehyde; epichlorohydrin.

\section{INTRODUCTION}

Enzyme immobilization on solid supports, besides facilitating the recovery and further re-use of the catalyst, offers important additional advantages. ${ }^{1,2}$ Indeed, immobilization avoids enzyme aggregation and autolysis, facilitates operational control, increases flexibility of reactor design and facilitates the removal from the reaction medium. ${ }^{3}$ Yet, additional stabilization of the immobilized enzyme three-dimensional structure may be achieved if an increase in the rigidification of the macromolecule structure is promoted, which can be accomplished if several bonds between enzyme and support are obtained. ${ }^{4}$

Lipases (triacylglycerol acyl hydrolases, E.C. 3.1.1.3) have been immobilized by several methods, namely adsorption, cross-linking, adsorption followed by cross-linking, covalent attachment and physical entrapment. ${ }^{5-13}$ However, the selection of an immobilization strategy should be based on process specifications for the catalyst, including parameters such as overall enzymatic activity, effectiveness of lipase utilization, deactivation and regeneration characteristics, costs of the immobilization procedure, toxicity of immobilization reactants and the desired final properties of the immobilized derivative on an industrial scale require their immobilization and re-usability. ${ }^{14,15}$ In this way, the multipoint covalent immobilization requires the interaction of several residues of the same enzyme molecule with active groups of the support. ${ }^{16,17}$ Enzyme stabilization is obtained after increasing the rigidity of a small part of its surface, which will turn the overall threedimensional structure more rigid. ${ }^{18,19}$

Aldehyde groups in the support and amine groups in the enzyme are a good choice to make the multipoint attachment and, therefore, to

*e-mail: jcs@unilab.edu.br obtain highly stable enzyme derivatives. ${ }^{19}$ Amine groups (terminal and in lysine residues) are very reactive, abundant on the enzyme surface and form Schiff bases with the aldehyde groups of the support. ${ }^{20}$ The number of covalent bonds between the support and the enzyme depends on the degree of activation of the support (concentration of aldehyde groups in the support surface) and on the concentration of amine groups in the enzyme molecule. ${ }^{21} \mathrm{pH}$ is an important variable in this immobilization approach, since lysine amine groups have $\mathrm{pK}$ around 10.5 , and will only be reactive at $\mathrm{pH} 10$ or above. ${ }^{22}$

Therefore, immobilization and stabilization of enzymes may make them still more attractive for industrial applications, facilitating their use under extreme conditions of temperature and $\mathrm{pH}$, as well as in the presence of organic solvents or any other distorting agent. Improvement of stability, nonetheless, is still one of the main issues for the implementation of enzymes as industrial biocatalysts. ${ }^{20}$

Due to the interesting properties of lipases as biocatalysts, several works report the immobilization of these enzymes using different protocols: adsorption on hydrophobic supports, entrapment in gels and covalent attachment to solid supports. ${ }^{23,24}$ Among lipases, the lipase from Rhizomucor miehei (RML) is available enzyme in both soluble and immobilized form, presenting high activity and good stability under diverse conditions; therefore, it has been employed from food industry to organic chemistry, from biodiesel production to fine chemicals. ${ }^{25,26}$ Thus, RML was chosen as model lipase for this study.

Chitosan, an abundant raw material, has been already used as support for lipase immobilization. ${ }^{27}$ This material is easily available in Ceará State, Brazil, due to the long extent of its seacoast and the high activity of its seafood industry. It is a natural cationic polysaccharide derived from chitin and is known as good support for enzyme immobilization because of its hydrophilicity, biocompatibility, and 
biodegradability; moreover, chitosan is obtained at a relatively low cost from shells of shellfish (mainly crab, shrimp, lobster, and krill), wastes of the seafood industry, and its utilization for enzyme immobilization constitutes an attractive option for disposal of crustaceans, shrimp and crab shell wastes. ${ }^{28}$ Chitosan has reactive amino and hydroxyl groups, which after further chemical modifications, can make covalent bonds with reactive groups of enzymes. ${ }^{1}$ Due to its amine groups, chitosan is a cationic polyelectrolyte $(\mathrm{pKa}=6.5)$ being insoluble in neutral aqueous solutions, but it is soluble in acidic solutions below $\mathrm{pH}$ 6.5. The mechanical properties of this polymer can be improved by further crosslinking using bifunctional reactants like glutaraldehyde. ${ }^{28}$ Chitosan amine groups can directly react with glutaraldehyde to generate aldehyde groups, which will in turn form Schiff bases with the enzyme. ${ }^{29}$ Chitosan hydroxyl groups can be also activated by using epoxide reactants like glycidol and epichlorohydrin, for instance, followed by oxidation with sodium periodate to produce reactive aldehyde-glyoxyl groups. ${ }^{30}$

The internal structure of the chitosan gel can be modified by interaction with other biopolymers such as alginate and carrageenan, with which chitosan may form hybrid gels. ${ }^{26,27}$ The biopolymers alginate and $\kappa$-carrageenan have groups that are negatively charged at neutral $\mathrm{pH}$ and can interact with the positively charged amine groups of chitosan, forming different internal nets. Carrageenans are a family of linear sulfated polysaccharides extracted from red seaweeds. ${ }^{31}$ They are large, highly flexible molecules that curl, forming helical structures that give them the ability to form a variety of different gels at room temperature, in the presence of some cations like potassium. $\mathrm{k}$-Carrageenan can form strong and rigid gels. ${ }^{32}$ Alginate induces the formation of stable polyelectrolytes with chitosan that are broken at strict $\mathrm{pH}$ and temperature conditions. ${ }^{33}$

This work aims to obtain high activity and thermal stable immobilized derivatives of the lipase from Rhizomucor miehei using hybrid matrices of chitosan and different copolymers as k-carrageenan and sodium alginate activated by glycidol, epichlorohydrin or glutaraldehyde, analyzing some parameters such as immobilization yield, recovered activity, and thermal stability at $60{ }^{\circ} \mathrm{C}$.

\section{MATERIALS AND METHODS}

\section{Materials}

Commercial lipase from Rhizomucor miehei $\left(2.6 \pm 6 \mathrm{U} \mathrm{mL}^{-1}\right)$ was purchased from Novozymes Latin America Ltd. (Araucária, Brazil) and was used as received. Powdered chitosan, $85.2 \%$ deacetylation degree, was kindly donated by Polymar Ind. Ltda. (Ceará, Brazil). Glycidol, epichlorohydrin, $p$-nitrophenyl butyrate ( $p$-NPB), sodium alginate, k-carrageenan and bovine serum albumin were acquired from Sigma-Aldrich Chemical Co. (St. Louis, MO). Glutaraldehyde $25 \%(\mathrm{~m} / \mathrm{v})$ was from Vetec (São Paulo, Brazil). Other reagents and solvents used were of analytical grade.

\section{Determination of enzyme activity and protein concentration}

The hydrolysis of $p$-NPB was used to follow the soluble and immobilized enzyme hydrolytic activities. Assays were performed by measuring the increase in the absorbance at $410 \mathrm{~nm}$ produced by the release of $p$-nitrophenol in the hydrolysis of $15 \mathrm{mmol} \mathrm{L}^{-1} p$-NPB in 2-propanol $100 \mathrm{mmol} \mathrm{L}^{-1}$ sodium phosphate buffer at $\mathrm{pH} 8$ and $25^{\circ} \mathrm{C} .{ }^{34}$ To initialize the reaction, $2 \mathrm{~mL}$ of lipase solution or suspension was added to $1 \mathrm{~mL}$ of substrate solution. One unit of $p$-NPB activity was defined as the amount of enzyme that is necessary to hydrolyze $1 \mu \mathrm{mol}$ of $p$-NPB per minute (U) under the conditions described previously.

Protein concentration was determined according to the procedure described by Bradford (1976) using bovine serum albumin (BSA) as standard. ${ }^{35}$

\section{Preparation of chitosan beads}

Chitosan beads were prepared by dissolving powder chitosan in an acetic acid 5\% v/v solution. The obtained solution of 2.5-5.0\% $(\mathrm{m} / \mathrm{v})$ was dropped into a gently stirred $0.1 \mathrm{~mol} \mathrm{~L}^{-1} \mathrm{NaOH}$ solution for $24 \mathrm{~h}$ at room temperature and washed with an excess of distilled water. ${ }^{36}$ Higher concentrations of polymer were not used due to the high viscosity, which makes the formation of beads difficult.

\section{Preparation of hybrid-chitosan beads}

Hybrid-chitosan beads were prepared by dissolving powder chitosan in acetic acid 5\% (v/v) solution. Afterward, sodium alginate or carrageenan was added to the solution, which was stirred for 10-30 min. The obtained solutions were sprayed into a gently stirred $0.1 \mathrm{~mol} \mathrm{~L}^{-1} \mathrm{NaOH}$ solution for $24 \mathrm{~h}$ at room temperature and dropped with distilled water. ${ }^{36}$ The obtained supports were chitosan $2.5 \%$-alginate $2.5 \%$ and chitosan $2.5 \%$-carrageenan $2.5 \%$, being all concentrations expressed as $\%(\mathrm{~m} / \mathrm{v})$.

\section{Chemical activation using glutaraldehyde}

Activation was made by contacting chitosan and hybrid-chitosan beads with sodium phosphate buffer $\left(0.1 \mathrm{~mol} \mathrm{~L}^{-1}, \mathrm{pH} 7.0\right)$ containing glutaraldehyde $5 \%(\mathrm{v} / \mathrm{v})$ using a ratio Vbeads/Vtotal of $1 / 10$ during $1.0 \mathrm{~h}$ at $25{ }^{\circ} \mathrm{C} .{ }^{20}$ Afterwards, the beads were washed with distilled water to remove the excess of the activating agent.

\section{Chemical activation using glycidol and epichlorohydrin}

Glyceryl-supports were prepared by mixing beads under stirring with an aqueous solution containing $1.7 \mathrm{~mol} \mathrm{~L}^{-1} \mathrm{NaOH}$ and $0.75 \mathrm{~mol} \mathrm{~L}^{-1} \mathrm{NaBH}_{4}$ (glycidol) ${ }^{37}$ or $2 \mathrm{~mol} \mathrm{~L}^{-1} \mathrm{NaOH}$ and $0.12 \mathrm{~mol} \mathrm{~L}^{-1}$ $\mathrm{NaBH}_{4}$ (epichlorohydrin) in ice bath. ${ }^{38}$ Then, $0.48 \mathrm{~mL}$ of glycidol or $2 \mathrm{~mL}$ of epichlorohydrin per gram of bead were added, kept under mechanical stirring for $18 \mathrm{~h}$ and washed until neutrality. Glyoxyl/ oxirane-supports were obtained by contacting beads with $2 \mathrm{~mL}$ of $0.1 \mathrm{~mol} \mathrm{~L}^{-1} \mathrm{NaIO}_{4}$ solution per gram of gel for $2.0 \mathrm{~h}$ under room temperature. ${ }^{39}$ Afterward, they were washed with an excess of distilled water until neutrality.

\section{Immobilization procedure}

Lipase from Rhizomucor miehei was immobilized on chitosan beads ( $200 \mathrm{U}_{p \text {-NPB }}$ of enzyme per gram of bead), after activation with glycidol, epichlorohydrin or glutaraldehyde. The immobilization was carried out in $100 \mathrm{mmol} \mathrm{L}^{-1}$ sodium bicarbonate buffer (ratio $\mathrm{m} / \mathrm{v}$ of $1 / 10$ ), $\mathrm{pH} 10.05$, at $25^{\circ} \mathrm{C}$ and incubation time of $5 \mathrm{~h}$, under mild stirring. $2 \mathrm{mg}$ of protein per gram of support was used for immobilization, prepared from a crude extract containing $10.8 \mathrm{mg}$ of protein per milliliter. The number of enzyme units/mL of enzyme and the protein mass $/ \mathrm{mL}$ of enzyme were calculated using the hydrolytic enzyme activity (previously described) and Bradford method (1976). ${ }^{35}$ The mass of enzyme and gel were weighted and the offered enzyme load could be calculated $\left(\mathrm{U} \bullet \mathrm{g}_{\mathrm{gel}}{ }^{-1}\right.$ and $\mathrm{mg}$ enzyme per gram of gel).

\section{Immobilization parameters}

The immobilization yield (IY) was calculated by measuring the difference between enzyme activities in the blank solution and in the 
supernatant before $\left(\mathrm{At}_{0}\right)$ and after $\left(\mathrm{At}_{\mathrm{f}}\right)$ immobilization, according to Eq. (1):

$$
I Y(\%)=\frac{\left(A t_{0}-A t_{f}\right)}{A t_{0}} \times 100
$$

Because the offered enzyme load was known, the number of enzyme units theoretically immobilized per gram of gel $\left(\mathrm{At}_{\text {theoretically immobilized }}\right)$ could be calculated. After finishing the immobilization, the apparent gel activity $\mathrm{At}_{\text {app }}$ (enzyme units $\bullet \mathrm{g}_{\mathrm{gel}}{ }^{-1}$ ) was measured and compared to the theoretically immobilized. The recovered activity was then calculated as $\mathrm{At}_{\text {app }}\left(\mathrm{U} \bullet \mathrm{g}_{\mathrm{gel}}{ }^{-1}\right) /$ $\mathrm{At}_{\text {theoretically immobilized }}\left(\mathrm{U} \bullet \mathrm{g}_{\mathrm{gel}}{ }^{-1}\right)$.

\section{Thermal stability assays}

Soluble enzyme and immobilized derivatives were incubated in a $0.1 \mathrm{~mol} \mathrm{~L}^{-1}$ sodium phosphate buffer and $\mathrm{pH} 7.0$ at $60^{\circ} \mathrm{C}$. Periodically, samples were withdrawn and their residual hydrolytic activities were assayed as described above. The single-step non-first-order model, proposed by Sadana and Henley ${ }^{40}$ was fitted to the experimental data. This model considers that a single step inactivation leads to a final state that exhibits a residual activity, which is very stable. The activity-time expression is

$$
A R=(1-\alpha) \times e^{-k d \times t}+\alpha
$$

In which, $A R$ is the activity (dimensionless), it is the ratio between the specific activity of the final state, $\mathrm{A}_{\mathrm{t}}$, and the one of the initial state, $\mathrm{At}_{0}$; and $\mathrm{k}_{\mathrm{d}}$ is the first-order deactivation rate constant $\left(\right.$ time $\left.^{-1}\right)$. The parameter $\mathrm{k}$ should describe the unfolding or the inactivation process and the parameter $\alpha$ describes the longterm level of activity (Pedroche et al.). ${ }^{21}$ Stabilization factor $\left(\mathrm{S}_{\mathrm{F}}\right)$ was given as the ratio between the half-life of the immobilized derivative and the half-life $\left(t_{1 / 2}\right)$ of the soluble enzyme at the same conditions.

\section{RESULTS AND DISCUSSION}

\section{Activation with glutaraldehyde: influence of the polymer} composition on the multipoint covalent attachment of lipase

Pure and hybrid chitosan gels were prepared and then activated with glutaraldehyde and used for RML immobilization at $\mathrm{pH} 10.05$ and $25{ }^{\circ} \mathrm{C}$ for $5 \mathrm{~h}$. Table 1 presents the immobilization parameters for these RML derivatives.

The results of Table 1 show that the formation of hybrid gels by mixing chitosan with $\kappa$-carrageenan or alginate, for the same total polymer concentration $(5.0 \%)$, may not have improved the internal structure of the matrix, as the obtained hybrid derivatives presented lower thermal stability when compared to pure chitosan. The best derivative was obtained using chitosan $5.0 \%$, recovered activity of $97 \%$ and 154-fold more stable than the soluble enzyme.

It can also be seen that the other significant variable was the polymer concentration. The increase of the chitosan concentration from 2.5 to $5.0 \%$ led to an increase in the immobilization yield and in the stabilization factor of the derivatives. These results may be explained by the increase of aldehyde groups available to link to the amine groups of the enzyme. The higher the polymer concentration, the higher the number of available amine groups in the support to react with glutaraldehyde. However, the high reactivity of this activating reactant also might have led to excessive cross-linking in the matrix and the formation of small pores. In consequence, the apparent activity of the immobilized enzyme did not increase.

The thermal stability of the produced derivatives was studied at $60{ }^{\circ} \mathrm{C}(\mathrm{pH} 7.0)$. The Sadana-Henley two-parameter deactivation model was fitted to the data (enzyme residual activities for different incubation times at $60^{\circ} \mathrm{C}$ ). Figure 1 shows the results. The calculated half-lives for the obtained biocatalysts are shown in Table 1.

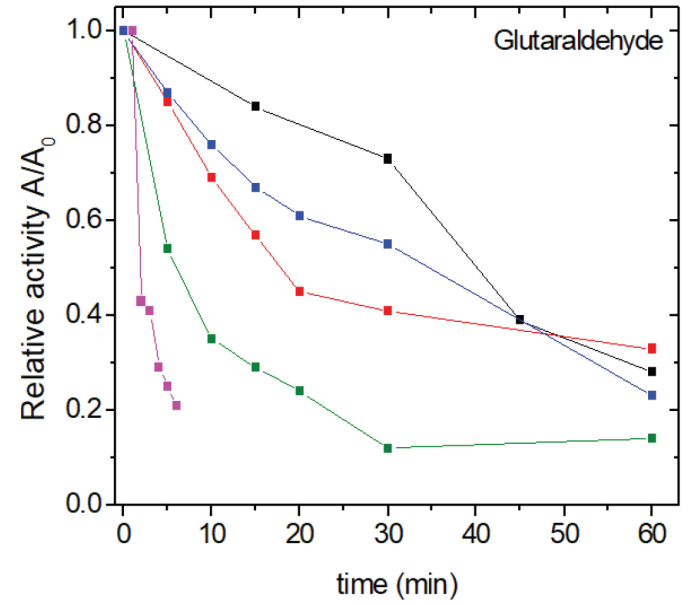

Figure 1. Thermal inactivation of pure and hybrid chitosan-glutaraldehyde derivatives. Immobilization at $\mathrm{pH} 10.05,25^{\circ} \mathrm{C}$, for $5 \mathrm{~h}$, offered enzyme load of $2 \mathrm{mg}$ of RML $\mathrm{g}_{\mathrm{gel}}{ }^{-1}\left(200 \mathrm{U} \mathrm{g}_{\mathrm{gel}}{ }^{-1}\right)$. Soluble enzyme and derivatives were incu-

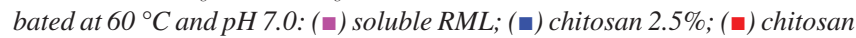
$5.0 \%$; (-) chitosan $2.5 \%$-alginate $2.5 \%$; (-) chitosan $2.5 \%$-carrageenan $2.5 \%$

\section{Activation with glycidol: influence of the polymer composition}

Table 2 / Figure 2 show the immobilization parameters for RML in pure and hybrid chitosan, activated with glycidol. Activation with glycidol led to a decrease in the stability factor, when compared to the activation with glutaraldehyde.

The enzyme immobilization through reaction between glyoxyl aldehyde groups of the support and amine groups of the enzyme requires the formation of at least two simultaneous bonds, which act in a synergistic way, but with weakly forces. This behavior may

Table 1. Influence of the polymer composition on the immobilization of lipase at $\mathrm{pH} 10.05,25{ }^{\circ} \mathrm{C}$, for $5 \mathrm{~h}$. Supports activated with glutaraldehyde, enzyme load: $200 \mathrm{U}_{p-\mathrm{NPB}}$ of enzyme $\mathrm{g}^{-1}$ of gel. Immobilization parameters: immobilization yield $\left(\mathrm{I}_{\mathrm{Y}}\right)$, recovered activity $\left(\mathrm{R}_{\mathrm{A}}\right)$, apparent activity $\left(\right.$ App), half-life $\left(\mathrm{t}_{1 / 2}\right)$ and

\begin{tabular}{|c|c|c|c|c|c|}
\hline Support & $\mathrm{I}_{\mathrm{Y}}(\%)$ & $\mathrm{R}_{\mathrm{A}}(\%)$ & $\begin{array}{c}\mathrm{App} \\
\left(\mathrm{U} \mathrm{g}_{\mathrm{gel}}^{-1}\right) \\
\end{array}$ & $\mathrm{t}_{1 / 2}(\mathrm{~min})$ & $\mathrm{S}_{\mathrm{F}}$ \\
\hline Chitosan $2.5 \%$ & 93 & 93 & 9 & 32 & 146 \\
\hline Chitosan $5.0 \%$ & 95 & 97 & 6 & 33 & 154 \\
\hline Chitosan 2.5\%-Alginate $2.5 \%$ & 68 & 36 & 25 & 5 & 24 \\
\hline Chitosan $2.5 \%$-Carrageenan $2.5 \%$ & 59 & 4 & 5 & 11 & 51 \\
\hline
\end{tabular}
stabilization factor $\left(\mathrm{S}_{\mathrm{F}}\right)$ at $60^{\circ} \mathrm{C}$ 
Table 2. Influence of the polymer composition on the immobilization of lipase at $\mathrm{pH} 10.05,25{ }^{\circ} \mathrm{C}$, for $5 \mathrm{~h}$. Supports activated with glycidol, enzyme load: $200 \mathrm{U}_{p \text {-NPB }}$ of enzyme $\mathrm{g}^{-1}$ of gel. Immobilization parameters: immobilization yield (IY), recovered activity (RA), apparent activity (App), half-life ( $\left.\mathrm{t}_{1 / 2}\right)$ and stabilization factor $\left(\mathrm{S}_{\mathrm{F}}\right)$ at $60{ }^{\circ} \mathrm{C}$

\begin{tabular}{lccccc}
\hline Support & $\mathrm{I}_{\mathrm{Y}}(\%)$ & $\mathrm{R}_{\mathrm{A}}(\%)$ & $\begin{array}{c}\mathrm{App} \\
\left(\mathrm{U} \mathrm{g}_{\mathrm{gel}}{ }^{-1}\right)\end{array}$ & $\mathrm{t}_{1 / 2}(\mathrm{~min})$ & $\mathrm{S}_{\mathrm{F}}$ \\
\hline Chitosan 2.5\% & 41 & 15 & 8 & 9 & 40 \\
Chitosan 5.0\% & 79 & 2 & 2 & 30 & 60 \\
Chitosan 2.5\%-Alginate 2.5\% & 25 & 15 & 5 & 14 & 64 \\
Chitosan 2.5\%-Carrageenan 2.5\% & 78 & 2 & 2 & 17 & 80 \\
\hline
\end{tabular}

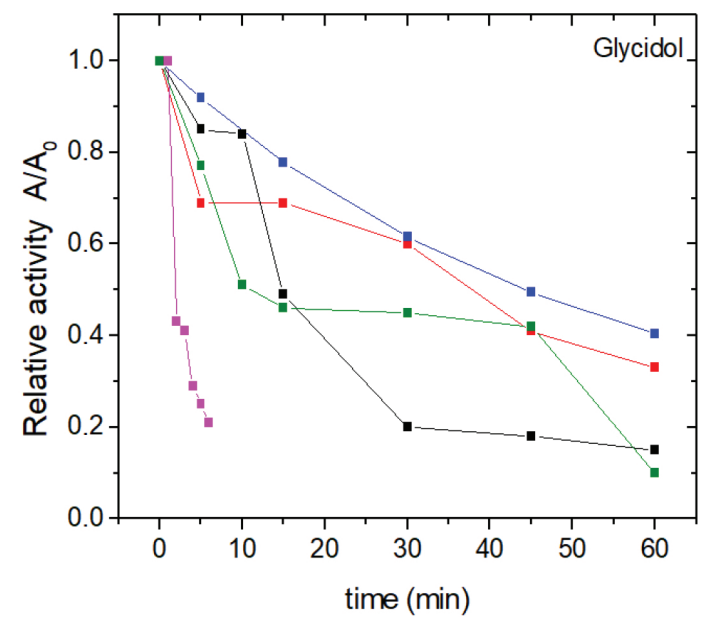

Figure 2. Thermal inactivation of pure and hybrid chitosan-glycidol derivatives. Immobilization at $\mathrm{pH} 10.05,25^{\circ} \mathrm{C}$, for $5 \mathrm{~h}$, offered enzyme load of $2 \mathrm{mg}$ of RML $g_{g e l}{ }^{-1}\left(200 \mathrm{Ug}_{g e l}{ }^{-1}\right)$. Soluble enzyme and derivatives were incubated at

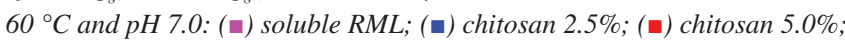
(匹) chitosan $2.5 \%$-alginate $2.5 \%$; (-) chitosan $2.5 \%$-carrageenan $2.5 \%$

explain the observed decrease in the stability factor of the chitosan glyoxyl derivatives. Probably, immobilization with glutaraldehyde was unipoint and, with glyoxyl, at least through two points. The chitosan-carrageenan derivative presented the best result, presenting $78 \%$ immobilization yield and stabilization factor of 80 at $60{ }^{\circ} \mathrm{C}$.

\section{Activation with epichlorohydrin: influence of the polymer composition}

Results in Table 3 / Figure 3 show that activation of pure and hybrid chitosan with epichlorohydrin led to a significant improvement in the thermal stability of the derivatives, when compared to the other two tested activating agents.

The most stable derivative, using epichlorohydrin, was the hybrid chitosan-alginate. Hence, the presence of different reactive groups in each polymer and the difference in reactivity of the activating agents have caused this nonmonotonic behavior. Besides the hydroxyl groups, the polymers have other different reactive groups: amine groups in chitosan, acidic groups in alginate, and sulfate groups in $\kappa$-carrageenan. The reaction of the amine groups of chitosan with epichlorohydrin generates epoxide groups, which are able to link to the enzyme, as well are the glyoxyl groups. Glycidol has epoxy and hydroxyl groups while epichlorohydrin has epoxy and chloride groups, being the latter one more reactive. On the other hand, chitosan has also two reactive groups, amine and hydroxyl, being the former ones more reactive than hydroxyl. Therefore, after the reaction with the epoxide reactants, probably many amine groups also reacted with the activating agents.

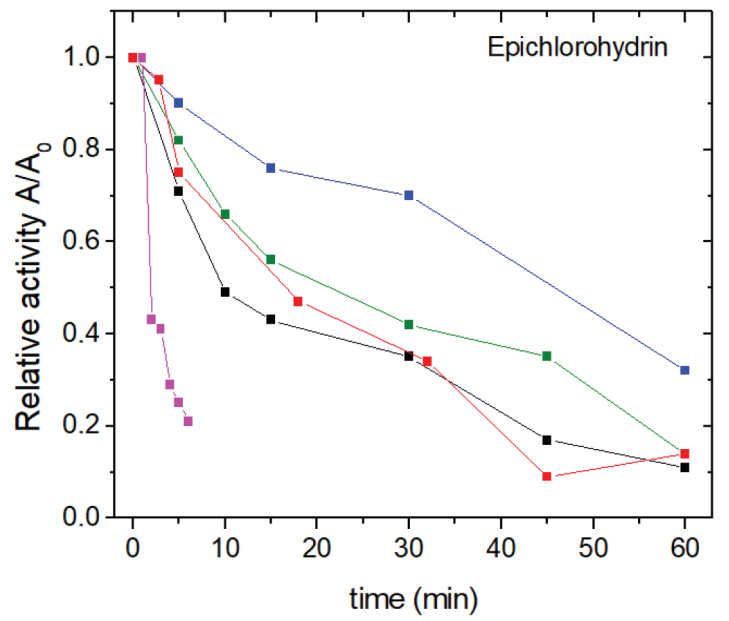

Figure 3. Thermal inactivation of pure and hybrid chitosan-epichlorohydrin derivatives. Immobilization at $\mathrm{pH} 10.05,25^{\circ} \mathrm{C}$, for $5 \mathrm{~h}$, offered enzyme load of $2 \mathrm{mg}$ of $R M L \mathrm{~g}_{g e l}{ }^{-1}\left(200 \mathrm{Ug}_{\text {gel }}{ }^{-1}\right)$. Soluble enzyme and derivatives were incu-

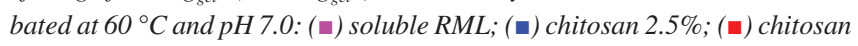
$5.0 \%$; ( ) chitosan $2.5 \%$-alginate $2.5 \%$; ( ) chitosan $2.5 \%$-carrageenan $2.5 \%$

Although it has been already reported that only few chitosan amine groups react with epichlorohydrin, the reaction conditions used in this work were stronger and it was expected that more amine groups were transformed into amino-diol. ${ }^{20}$ As epichlorohydrin is more reactive than glycidol, more aldehyde groups in the support might

Table 3. Influence of the polymer composition on the immobilization of lipase at $\mathrm{pH} 10.05,25{ }^{\circ} \mathrm{C}$, for $5 \mathrm{~h}$. Supports activated with epichlorohydrin, enzyme load: $200 \mathrm{U}_{p-\mathrm{NPB}}$ of enzyme $\mathrm{g}^{-1}$ of gel. Immobilization parameters: immobilization yield $\left(\mathrm{I}_{\mathrm{Y}}\right)$, recovered activity $\left(\mathrm{R}_{\mathrm{A}}\right)$, apparent activity $(\mathrm{App})$, half-life $\left(\mathrm{t}_{1 / 2}\right)$ and stabilization factor $\left(\mathrm{S}_{\mathrm{F}}\right)$ at $60^{\circ} \mathrm{C}$

\begin{tabular}{|c|c|c|c|c|c|}
\hline Support & $\mathrm{I}_{\mathrm{Y}}(\%)$ & $\mathrm{R}_{\mathrm{A}}(\%)$ & $\begin{array}{c}\mathrm{App} \\
\left(\mathrm{U} \mathrm{g}_{\mathrm{gel}}{ }^{-1}\right)\end{array}$ & $\mathrm{t}_{1 / 2}(\min )$ & $\mathrm{S}_{\mathrm{F}}$ \\
\hline Chitosan $2.5 \%$ & 62 & 14 & 11 & 17 & 80 \\
\hline Chitosan $5.0 \%$ & 59 & 13 & 18 & 2 & 11 \\
\hline Chitosan $2.5 \%$-Alginate $2.5 \%$ & 64 & 5 & 10 & 20 & 93 \\
\hline Chitosan 2.5\%-Carrageenan $2.5 \%$ & 57 & 10 & 11 & 12 & 53 \\
\hline
\end{tabular}


be formed using this activating agent, which allowed the formation of more bonds between enzyme and support, thus explaining the increase in the stability factor. The best results were obtained for chitosan $2.5 \%$-alginate $2.5 \%$, which presented a stabilization factor of 93 (at $60^{\circ} \mathrm{C}$ ). The different reactivity of the involved groups and the helicoidal conformation of $\kappa$-carrageenan, which may lead to the formation of a better internal gel structure, may be responsible for this result. ${ }^{33}$

\section{General considerations}

\section{RML thermostability}

Many lipases have been engineered to enhance thermostability, including RML. ${ }^{41}$ Thermostability is one of the most important factors for the reaction rate once high temperatures favor mass transfer. Lipase with better thermostability can bear higher reaction temperatures thus benefiting the reaction rate and making the industrial processes more efficient. ${ }^{41-43}$ The optimum temperature RML depends on several factors. As each immobilized system has its own characteristics, changes in kinetics parameters may occur or not, and it is influenced by several variables, such as enzyme source, kind of support, immobilization method, and enzyme-support interactions. $^{44}$

A study from Mohammadi et al. indicated that immobilized RML retained 90 and $85 \%$ of its initial activity after $24 \mathrm{~h}$ of incubation at 50 and $55^{\circ} \mathrm{C}$, respectively; and, when temperature increased to 60 and $65{ }^{\circ} \mathrm{C}$, approximately 50 and $20 \%$ of its initial activity was retained. ${ }^{45}$ On the other hand, the study from Babaki et al. revealed that this immobilized RML retained about 89 and $69 \%$ of its initial activity after $24 \mathrm{~h}$ incubation at 60 and $80{ }^{\circ} \mathrm{C}$ respectively. ${ }^{46}$

In a work from Skoronskiet al., the immobilized lipase Lipozyme $^{\circledR}$ RM IM was applied in a continuous bioreactors for ester synthesis. The deactivation of the biocatalyst was observed during the reaction as a function of temperature and the substrate/ enzyme ratio, as well as the water produced by the esterification reaction. In this study, higher conversions were obtained at $40{ }^{\circ} \mathrm{C}$, while a larger amount of ester was produced when the reaction was carried out at $30^{\circ} \mathrm{C} .{ }^{47}$

RML was chosen as the biocatalyst for this manuscript, in view of its successful utilization in various synthetic reactions. ${ }^{26}$ This can be attributable to the strong specificity and catalytic versatility of RML, as well as its very high catalytic activity under the wide temperature range from 40 to $80{ }^{\circ} \mathrm{C}^{45,48-51}$

\section{Performance of the hybrid matrices}

The purpose of this work was to prepare chitosan-based hybrid polyelectrolytes (sodium alginate or carrageenan) matrices. Specifically, chitosan and carrageenan form a strong ionic bond between each other due to electrostatic attraction between oppositely charged amino groups of chitosan and sulfate groups of carrageenan. ${ }^{52}$ In this present manuscript, we optimized the concentration of chitosan and carrageenan in solution and their blend composition, to enable the formation of desired complexes for fabricating the chitosan-based hybrid matrices. Furthermore, different structures were obtained using chitosan with another biopolymer, such as alginate, gelatin, or $\kappa$-carrageenan. Changing the structure of the gel can significantly improve the covalent multipoint immobilization of the enzymes and considerably improved thermostability compared to pure chitosan hydrogels. ${ }^{36,52}$

As hybrid hydrogels are highly hydrophilic, their use as a support for enzymes requires chemical modification of the matrix, using hydrophobic agents to improve the intragel microenvironment, favoring multipoint covalent immobilization of enzymes. ${ }^{36,53-55}$
Therefore, this work sought to prepare chitosan gels (sodium alginate or carrageenan) modified with glycidol (GLY), epichlorohydrin (EPI) or glutaraldehyde (GLU) groups to obtain highly active and thermostable lipase derivatives by multipoint covalent immobilization of RML in complexes of chitosan polyelectrolytes.

\section{CONCLUSIONS}

In this work, a very significant improvement in thermal stability of RML was achieved after the covalent attachment of the enzyme on chitosan. The half-life of immobilized RML could be increased from $11 \mathrm{~min}$ to $54 \mathrm{~min}$ at $60^{\circ} \mathrm{C}$. The less stable derivative was obtained using pure chitosan $2.5 \%$ activated with glutaraldehyde. The more stable RML was immobilized on a hybrid gel, chitosan $2.5 \%$-carrageenan $2.5 \%$, activation of the support with epichlorohydrin. This best derivative was 154-fold more stable than the soluble enzyme, with chitosan $5.0 \%$ beads, using glutaraldehyde. When epichlorohydrin was used, a higher number of reactive groups was generated in the support. In consequence, more residues of the enzyme were involved in the multipoint attachment, which led to a higher stability. It is possible to note an increment of stability according to activation method, following different chemistries, has offered very different properties. Thus, it is possible to improve its characteristics aiming lipase stabilization.

\section{ACKNOWLEDGMENTS}

We gratefully acknowledge the financial support of Brazilian Agencies for Scientific and Technological Development, Fundação Cearense de Apoio ao Desenvolvimento Científico e Tecnológico - FUNCAP, Conselho Nacional de Desenvolvimento Científico e Tecnológico - CNPq and Coordenação de Aperfeiçoamento de Ensino Superior (CAPES).

\section{REFERENCES}

1. Reis, C.; Sousa, E.; Serpa, J.; Oliveira, R.; Oliveira, R.; Santos, J.; Quim. Nova 2019, 42, 768.

2. DiCosimo, R.; McAuliffe, J.; Poulose, A. J.; Bohlmann, G.; Chem. Soc. Rev. 2013, 42, 6437.

3. Sheldon, R. A.; van Pelt, S.; Chem. Soc. Rev. 2013, 42, 6223.

4. Carvalho, N. B.; Lima, Á. S.; Soares, C. M. F.; Quim. Nova 2014, 40, 298.

5. Rios, N. S.; Morais, E. G.; Galvão, W. S.; Andrade Neto, D. M.; dos Santos, J. C. S.; Bohn, F.; Correa, M. A.; Fechine, P. B. A.; FernandezLafuente, R.; Gonçalves, L. R. B.; Int. J. Biol. Macromol. 2019, 141, 313.

6. Pinheiro, M. P.; Monteiro, R. R. C.; Silva, F. F. M.; Lemos, T. L. G.; Fernandez-Lafuente, R.; Gonçalves, L. R. B.; dos Santos, J. C. S.; Process Biochem. 2019, 87, 128.

7. Monteiro, R. R. C.; Neto, D. M. A.; Fechine, P. B. A.; Lopes, A. A. S.; Gonçalves, L. R. B.; dos Santos, J. C. S.; de Souza, M. C. M.; Fernandez-Lafuente, R.; Int. J. Mol. Sci. 2019, 20, 5807.

8. da Fonseca, A. M.; dos Santos, J. C. S.; de Souza, M. C. M.; de Oliveira, M. M.; Colares, R. P.; de Lemos, T. L. G.; Braz-Filho, R.; Ind. Crops Prod. 2020, 145, 111890.

9. Arana-Peña, S.; Rios, N. S.; Mendez-Sanchez, C.; Lokha, Y.; Carballares, D.; Gonçalves, L. R. B.; Fernandez-Lafuente, R.; Int. J. Biol. Macromol., in press.

10. Freitas, L.; Perez, V. H.; Santos, J. C.; de Castro, H. F.; J. Braz. Chem. Soc. 2007, 18, 1360

11. Arana-Peña, S.; Rios, N. S.; Mendez-Sanchez, C.; Lokha, Y.; Gonçalves, L. R. B.; Fernández-Lafuente, R.; Enzyme Microb. Technol. 2020, 137, 109535. 
12. Bezerra, R. M.; Monteiro, R. R. C.; Neto, D. M. A.; da Silva, F. F. M.; de Paula, R. C. M.; de Lemos, T. L. G.; Fechine, P. B. A.; Correa, M. A.; Bohn, F.; Gonçalves, L. R. B.; dos Santos, J. C. S.; Enzyme Microb. Technol. 2020, 138, 109560.

13. Moreira, K. S.; Moura Júnior, L. S.; Monteiro, R. R. C.; de Oliveira A. L. B.; Valle, C. P.; Freire, T. M.; Fechine, P. B. A.; de Souza, M. C. M.; Fernandez-Lorente, G.; Guisan, J. M.; dos Santos, J. C. S.; Catalyst 2020, 10, 414 .

14. Brady, D.; Jordaan, J.; Biotechnol. Lett. 2009, 31, 1639.

15. Mendes, A. A.; de Castro, H. F.; Pereira, E. B.; Furigo Júnior, A.; Quim Nova 2005, 28, 296

16. dos Santos, J. C. S.; Rueda, N.; Sanchez, A.; Villalonga, R.; Gonçalves, L. R. B.; Fernandez-Lafuente, R.; RSC Adv. 2015, 5, 35801.

17. Rodrigues, R. C.; Hernandez, K.; Barbosa, O.; Rueda, N.; Garcia-Galan, C.; dos Santos, J. C. S.; Berenguer-Murcia, A.; Fernandez-Lafuente, R.; Curr. Org. Chem. 2015, 19, 1707.

18. Rodrigues, R. C.; Ortiz, C.; Berenguer-Murcia, Á.; Torres, R.; Fernández-Lafuente, R.; Chem. Soc. Rev. 2013, 42, 6290.

19. Secundo, F.; Chem. Soc. Rev. 2013, 42, 6250.

20. Rodrigues, D. S.; Mendes, A. A.; Adriano, W. S.; Gonçalves, L. R. B.; Giordano, R. L. C.; J. Mol. Cat. B: Enzym. 2008, 51, 100.

21. Pedroche, J.; del Mar Yust, M.; Mateo, C.; Fernández-Lafuente, R.; Girón-Calle, J.; Alaiz, M.; Vioque, J.; Guisán, J. M.; Millán, F.; Enzyme Microb. Technol. 2007, 40, 1160.

22. Mateo, C.; Palomo, J. M.; Fernandez-Lorente, G.; Guisan, J. M.; Fernandez-Lafuente, R.; Enzyme Microb. Technol. 2007, 40, 1451.

23. Villeneuve, P.; Muderhwa, J. M.; Graille, J.; Haas, M. J.; J. Mol. Catal. B: Enzym. 2000, 9, 113.

24. Balcão, V. M.; Paiva, A. L.; Xavier Malcata, F.; Enzyme Microb. Technol. 1996, $18,392$.

25. Rodrigues, R. C.; Fernandez-Lafuente, R.; J. Mol. Catal. B: Enzym. 2010, 64, 1.

26. Rodrigues, R. C.; Fernandez-Lafuente, R.; J. Mol. Catal. B: Enzym. 2010, 66, 15.

27. Krajewska, B.; Enzyme Microb. Technol. 2004, 35, 126.

28. Negm, N. A.; Hefni, H. H. H.; Abd-Elaal, A. A. A.; Badr, E. A.; Abou Kana, M. T. H.; Int. J. Biol. Macromol. 2020, 152, 681.

29. Ravishankar, K.; Dhamodharan, R.; React. Funct. Polym. 2020, 149, 104517.

30. Lan, D.-H.; Fan, N.; Wang, Y.; Gao, X.; Zhang, P.; Chen, L.; Au, C.-T.; Yin, S.-F.; Chin. J. Catal. 2016, 37, 826.

31. Campo, V. L.; Kawano, D. F.; da Silva, D. B.; Carvalho, I.; Carbohydr. Polym. 2009, 77, 167.
32. van de Velde, F.; Food Hydrocolloids 2008, 22, 727.

33. Dragan, E. S.; Dinu, M. V.; React. Funct. Polym. 2020, 146, 104372.

34. Bhatnagar, T.; Boutaiba, S.; Hacene, H.; Cayol, J.-L.; Fardeau, M.-L.; Ollivier, B.; Baratti, J. C.; FEMS Microbiol. Lett. 2005, 248, 133.

35. Bradford, M.; Anal. Biochem. 1976, 72, 248.

36. Mendes, A. A.; de Castro, H. F.; Rodrigues, D. S.; Adriano, W. S.; Tardioli, P. W.; Mammarella, E. J.; Giordano, R. C.; Giordano, R. L. C.; J. Ind. Microbiol. Biotechnol. 2011, 38, 1055.

37. Guisán, J. M.; Enzyme Microb. Technol. 1988, 10, 375

38. Beppu, M.; J. Membr. Sci. 2004, 240, 227.

39. Mateo, C.; Abian, O.; Fernandez-Lafuente, R.; Guisan, J. M.; Enzyme Microb. Technol. 2000, 26, 509.

40. Sadana, A.; Henley, J. P.; Biotechnol. Bioeng. 1987, 30, 717.

41. Bassegoda, A.; Cesarini, S.; Diaz, P.; Comput. Struct. Biotechnol. J. 2012, 2, e201209005.

42. Han, Z.; Han, S.; Zheng, S.; Lin, Y.; Appl. Microbiol. Biotechnol. 2009, $85,117$.

43. Zhang, J.; Lin, Y.; Sun, Y.; Ye, Y.; Zheng, S.; Han, S.; Enzyme Microb. Technol. 2012, 50, 325.

44. Bruno, L. M.; Coelho, J. S.; Melo, E. H. M.; Lima-Filho, J. L.; World J. Microbiol. Biotechnol. 2005, 21, 189.

45. Mohammadi, M.; Habibi, Z.; Dezvarei, S.; Yousefi, M.; Samadi, S.; Ashjari, M.; Process Biochem. 2014, 49, 1314.

46. Babaki, M.; Yousefi, M.; Habibi, Z.; Mohammadi, M.; Yousefi, P.; Mohammadi, J.; Brask, J.; Renewable Energy 2016, 91, 196.

47. Skoronski, E.; Padoin, N.; Soares, C.; Furigo Jr., A.; Braz. J. Chem. Eng. 2014, 31, 633 .

48. Abd Manan, F. M.; Attan, N.; Zakaria, Z.; Mahat, N. A.; Abdul Wahab, R.; J. Biotechnol. 2018, 280, 19.

49. Zhong, N.; Chen, W.; Liu, L.; Chen, H.; Food Chem. 2019, 271, 739.

50. Noël, M.; Lozano, P.; Combes, D.; Bioprocess Biosyst. Eng. 2005, 27, 375 .

51. Noel, M.; Combes, D.; J. Biotechnol. 2003, 102, 23.

52. Adriano, W. S.; Mendonça, D. B.; Rodrigues, D. S.; Mammarella, E. J.; Giordano, R. L. C.; Biomacromolecules 2008, 9, 2170.

53. Pereira, R. M.; Andrade, G. S. S.; Castro, H. F. D.; Campos, M. G. N.; Mater. Res. 2017, 20, 190.

54. Liu, Q.; Hua, Y.; Kong, X.; Zhang, C.; Chen, Y.; J. Mol. Catal. B: Enzym. 2013, 95, 89.

55. Wang, J.; Miao, X.; Fengzhao, Q.; Ren, C.; Yang, Z.; Wang, L.; RSC Adv. 2013, 3, 16739. 